\title{
Dignity in care: where next for nursing ethics scholarship and research?
}

\author{
DIGNIDADE NO CUIDADO: COMO PROSSEGUIR NOS ESTUDOS E NA PESQUISA \\ SOBRE ÉTICA EM ENFERMAGEM?
}

\author{
DIGNIDAD DEL CUIDADO: ¿QUÉ SE PLANTEA COMO FUTURO PARA ESTUDIOS E \\ INVESTIGACIONES DE ÉTICA EN ENFERMERÍA?
}

\author{
Ann Gallagher', Elma Lourdes Campos Pavone Zaboli², Carla Ventura ${ }^{3}$
}

\begin{abstract}
Dignity is recognised as both a central and also a contested value in bioethics discourse. The aim of this manuscript is to examine some of the key strands of the extensive body of dignity scholarship and research literature as it relates to nursing ethics and practice. The method is a critical appraisal of selected articles published in Nursing Ethics and other key manuscripts and texts identified by researchers in the UK and Brazil as influential. The results suggest a wide and rather confusing range of perspectives and findings albeit with some overall themes relating to objective and subjective features of dignity. In conclusion, the authors point to the need for more sustained philosophical engagement contextualising human dignity within a plurality of professional values. Future empirical work should explore what matters to patients, families, professionals and citizens in different cultural contexts rather than foregrounding qualitative research with such a contested concept.
\end{abstract}

\section{DESCRIPTORS}

Ethics, nursing

Bioethics

Personhood

Humanism

\section{RESUMO}

A Dignidade é reconhecida como valor central e, também, controverso no discurso bioético. $\mathrm{O}$ objetivo deste artigo é examinar algumas das vertentes principais da extensa produção acadêmica e de literatura sobre o tema, na ética e prática da enfermagem. 0 método é a avaliação crítica de uma seleção de artigos publicados na Nursing Ethics e de outros manuscritos e textos identificados como influentes por pesquisadores do Reino Unido e Brasil. Os resultados sugerem um leque amplo e confuso de perspectivas e achados, embora haja temas gerais relacionados às características objetivas e subjetivas da dignidade. Em conclusão, os autores apontam para a necessidade de sólidos estudos filosóficos para contextualizar a dignidade humana dentro da pluralidade de valores profissionais. Pesquisas empíricas futuras devem explorar o que importa para pacientes, familiares, profissionais e cidadãos em diferentes contextos culturais, em vez de seguir desenvolvendo pesquisas qualitativas embasadas em um conceito impreciso e contestado.

\section{DESCRITORES}

Ética em enfermagem

Bioética

Pessoalidade

Humanismo

\section{RESUMEN}

La dignidad es reconocida como un valor fundamental y, también, controvertido en el discurso bioético. El propósito del artículo es examinar algunos de los aspectos principales de la producción académica y bibliográfica sobre el tema en la ética y práctica de enfermería. El método es una evaluación crítica de una selección de artículos del Nursing Ethics y de otros textos identificados como influyentes por investigadores del Reino Unido y Brasil. Los resultados plantean la amplitud y confusión de perspectivas y conclusiones, aunque hay temas generales relacionados con características objetivas y subjetivas de la dignidad. En conclusión, los autores señalan la necesidad de sólidos estudios filosóficos a fin de contextualizar la dignidad humana en la pluralidad de valores profesionales. Los futuros estudios empíricos deben explorar lo importante para pacientes, familias, profesionales y ciudadanos en diferentes contextos culturales, en lugar de seguir desarrollando investigaciones cualitativas basadas en un concepto impreciso y controvertido.

\section{DESCRIPTORES}

Ética en enfermería

Bioética

Personeidad

Humanismo

${ }^{1} \mathrm{PhD}, \mathrm{MA}, \mathrm{BA}$ (Hons), PGCEA, RMN, SRN. Reader of Nursing Ethics. Director of the International Centre for Nursing Ethics. School of Health and Social Care, University of Surrey, UK. a.gallagher@surrey.ac.uk ${ }^{2}$ Dr.PH, MB, RN. Associate Professor. School of Nursing, University of São Paulo. São Paulo, SP, Brasil. elma@usp.br ${ }^{3} \mathrm{PhD}$, LLM, BA. Associate Professor at Ribeirão Preto College of Nursing.of the University of São Paulo. Ribeirão Preto, SP, Brazil. caaventu@eerp.usp.br 


\section{INTRODUÇÃO}

Dignity has become a hot topic for debate in bioethics circles. It has been embraced by many academics as a value worthy of philosophical attention and dismissed by some as a useless ${ }^{(1)}$ and squishy ${ }^{(2)}$ concept. Much of the impetus for the focus on dignity in relation to healthcare in the UK can be attributed to the increase in reports of indignity in care. In response to such reports, a Commission for Improving Dignity in Care in the UK was established in 2011. The Commission produced a report Delivering Dignity ${ }^{(3)}$ which made recommendations for educators and healthcare providers. In addition to attention received from philosophers, researchers, and nurse ethicists, dignity appears as a core value in professional codes and human rights declarations. However, dignity remains a contested concept and there is no consensus regarding its meaning or the most appropriate version of the concept for nursing practice.

It is timely to engage in cross-cultural discussion regarding the state of the art of dignity scholarship and research. We need to respond to questions such as: What can we learn from selected philosophical analyses of the concept?; What can we glean from manuscripts in the international journal Nursing Ethics that have detailed a wide range of studies exploring patient and professional perspectives on dignity in care?; And, crucially, what should the next steps be for nursing ethics and scholarship regarding dignity in care with a view to enhancing the patient and family experience and strengthening the value base of the nursing profession?

\section{INDIGNITY IN CARE}

In the UK, reports from the Patients' Association, the Care Quality Commission (and the healthcare Ombudsman detailed the poor experiences of patients and relatives. The Patients' Association ${ }^{(4-5)}$ reports gave examples of the neglect and indignity experienced by patients and families. The Care Quality Commission report ${ }^{(6)}$ focused on 'nutrition and dignity' and provided examples of disrespect for patients' privacy, call bells being placed out of reach of patients and of communication with patients that was not disrespectful. The Ombudsman report 'Care and

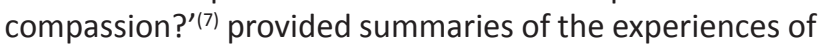
ten patients and families who had reason to complain to the National Health Service. The report states ${ }^{(7)}$ :

These were individuals who put up with difficult circumstances and didn't want to make a fuss. Like all of us, they wanted to be cared for properly and, at the end of their lives, to die peacefully and with dignity. What they have in common is their experience of suffering unnecessary pain, indignity and distress while in the care of the NHS.
A book published in 2011 by Michael Mandelstam Neglect and abuse in our health services ${ }^{(8)}$ detailed many more harrowing examples of poor care and unethical practice in the UK. In the chapter All the bad practice, Mandelstam shares the stories of patients who suffered due to deficits in fundamental care and disrespectful treatment from staff. Mandelstam's book also examines some of the many dignity-promoting initiatives in place in the UK. Alongside these reports, have been a wide range of media headlines and campaigns under the heading of dignity in care and undercover documentaries revealing unethical practice towards some of the most vulnerable patients in the $\mathrm{UK}^{(9-12)}$.

Reports evaluating the Brazilian Unified Health System (SUS) also show problems in relation to the delivery of respectful health care, the confidentiality of medical records and privacy during healthcare appointments. There are long delays in getting appointments, examinations and hospital admissions. Patients complain about disrespectful and rude treatment by health staff; low resolution of their health problems; and staff shortage. A report regarding what Brazilian think about SUS points to the lack of nurses, physicians, dentists, medicines, available beds in hospitals, and ambulances. Lack and delay are words frequently used in this report and suggest a range of unethical healthcare practices ${ }^{(13)}$.

In response to these challenges the Brazilian Health Ministry established a National Policy of Humanization of SUS (PNH) ${ }^{(14)}$. PNH results from the convergence of three main goals: to respond to the challenges regarding the quality and dignity in health care, to join up initiatives of health humanization in the SUS; and confront the adverse consequences arising from problems in the organization and management of health work.

The PNH proposes a new relationship between users, professionals and community. The idea is to have all of them working together to make the SUS more welcoming, more agile, with more comfortable places through the implementation of structural and attitudinal changes. The changes includes: reduction of waiting times; the presence of a companion in admissions and consultations; an open and democratic administration with a participative management; improvement of working conditions and improvement of healthcare professionals capabilities and skills; a friendly and pleasant atmosphere at health facilities, and the promotion of the welfare of users and health professionals: A statement from the Brazilian Minister of Health ${ }^{(15)}$ is as follows:

This should be implemented with the consequent creation of solidarity links between professionals and population, engaged in the construction of collective strategies that promote changes in practices of the services, with the ethical defence and an affirmation of a dignified living. 
PNH relates, therefore, to dignity and respect in the healthcare services and to dignified and respectful treatment:

Trends in Brazilian bioethics reveal a concern with human dignity. Protective Bioethics is one of these trends and is a type of response to unethical and unjust health care. It establishes populations who lack the resources to ensure the basic conditions for a life with dignity and not of mere survival(16). The bioethical problems of utmost important measures to protect the vulnerable individuals and to affirm dignity in health are those of justice, equity, fairness, allocation of scarce resources, and empowerment of users. Author ${ }^{(17)}$ describes protective bioethics as follows:

Protective Bioethics can be thought in both senses: strict and broad. In the strict sense, aims to give support to subjects and populations that do not have sufficient competence - or capacitation (capability) - to realize their projects of a fair and reasonable life, ie capable of achieve a dignified life as it is advocated by the so-called culture of human rights, and as it is morally right and necessary for the human society.

What we might conclude from the many examples of unethical practice - and patients' experience of, what has been referred to as, indignity in care - is likely to come about from a complex mix of individual, organisational and possibly also social and political factors. What is perhaps most perplexing is why developments in bioethics and nursing ethics more specifically appear to have had so little impact on the professionals and organisations who perpetuate these practices. Nursing ethics research relating to moral distress, moral sensitivity, empathy and the ethical or moral climate of healthcare organisations can however throw light on the complex interaction amongst these factors ${ }^{(18-21)}$.

\section{DIGNITY DECLARATIONS AND PROFESSIONAL CODES}

The concept of human dignity and the relationship between dignity and human rights have been important issues in contemporary international academia. Therefore, the concept of dignity should become indispensable in theoretical investigations on human rights. It has been argued that the idea of human dignity has developed through three historical stages in the West. The period of ancient Greece to Kant is said to be the philosophicaltheoretical period ${ }^{(22)}$. Following, the concept of dignity entered into a political period in the mid-19th century, standing as a banner and guiding labor movements to seek for living conditions conforming to the notions of human dignity. Since the mid-1990s, the idea of dignity has entered a crucial period of legal construction. Based on profound reflections upon the inhuman actions of the Nazis and the political demands made by national liberation movements of countries of Asia, Africa and Latin America against Western colonialism and racialism, two conceptions of human dignity and human rights were adopted, simultaneously, in the Charter of the United Nations and the Universal Declaration of Human Rights ${ }^{(23)}$.

Thus, Article 1 of the Universal Declaration of Human Rights $^{(24)}$ states that:

All human beings are born free and equal in dignity and rights.

The Declaration associates the concept of dignity with human freedom and the capacity of human beings to shape their own destinies through the exercise of reason and a social order based on equality and mutual respect.

Through these documents, dignity was recognized as one of the most important human values which began to be solidified into a legal principle generally recognized by the international society, becoming a prevalent international ethical term. In other words, the concept of human dignity is acknowledged as the foundation for universal justice, peace and freedom initiatives around the world, as evidenced in the variety of human rights protocols currently accepted ${ }^{(25)}$.

The UK Human Rights Act $1998^{(26)}$ does not make dignity a right in the positive sense but does prohibit treatment that causes indignity. Article 3 makes explicit the:

Prohibition of torture: no one shall be subjected to torture or to inhuman or degrading treatment or punishment.

In this context, the constitutions of many Western countries have adopted the concept of human dignity and not infrequently give it the status of being the highest principle of law. This was the case of Brazil, in which human dignity is considered a core constitutional principle ${ }^{(27)}$.

Unlike Brazil, the UK does not have a national legally enforceable constitution, however there is a constitution for the National Health Service ${ }^{(28)}$ setting out the rights and responsibilities for patients and professionals. In relation to dignity, the constitution states:

You have a right to be treated with dignity and respect, in accordance with your human rights (28 Section 2a).

There are then a wide range of directives from professional, statutory and non-statutory sources and dignity assumes a central role in professional codes for nurses. The International Council of Nurses' code ICN Code ICN Code $^{(29)}$ states that:

Inherent in nursing is respect for human rights, including cultural rights, the right to life and choice, to dignity and to be treated with respect.

In the UK code ${ }^{(30)}$, nurses and midwives are directed to justify the trust of the people in their care by:

Make the care of people your first concern, treating them as individuals and respecting their dignity.

The Brazilian nurses' code $^{(31)}$ states in its basic principles that: 
Nursing professionals respect life, dignity and human rights, in all its dimensions.

Although dignity is mentioned in these instruments, none of them specify exactly what is meant by dignity or engage in any sustained philosophical analysis of this complex and contested concept. Thus, the notion of dignity is in the heart of the major international human right instruments as an important philosophical, ethical, and legal concept, but it has no agreed definition. We turn next to the insights that might be gleaned from the philosophical literature on dignity in care.

\section{DIGNITY IN CARE: PHILOSOPHICAL ANALYSES}

Attention to dignity is thriving in health and nursing research and advocacy ${ }^{(32)}$. One of the first philosophical analyses of dignity in relation to nursing was published in 1998 by David Seedhouse and Leila Shotton (now Toiviainen) ${ }^{(33)}$ in the journal Nursing Ethics. They argued that the maintenance of dignity is dependent on the person's ability to exercise competencies or to have help to do so in particular circumstances. They stated that dignity relates to the:

Interplay between circumstances and capabilities - We

lack dignity when we find ourselves in inappropriate cir-

cumstances, when we are in situations where we feel fool-

ish, incompetent, inadequate or unusually vulnerable (33).

Studies ${ }^{(33)}$ compared dignity to the construction of a brick wall. Dignity is made up of numerous capabilities (bricks) of different kinds assembled during life years. When one or a few bricks are lost, dignity can be lost too, and the possibilities to regain it depend on which capabilities were affected. The authors distinguished between different levels of dignity loss, although, they recognized that these levels are not absolutely separate categories. In the first level dignity in maintained. In the second, dignity is lost in a trivial way and can be easily restored. The serious loss of dignity in the third level requires a substantial effort to restore it. And, finally, in the fourth level there is a devastating loss of dignity and it is impossible to regain dignity without help from others.

The same authors ${ }^{(33)}$ stated that certain provisions or conditions are necessary to the dignity of any human being because, in order to be capable everyone needs certain resources. As an example, they pointed that to carry out daily life people usually need physical strength, information, freedom from debilitating thoughts, emotions, and overwhelming life stresses. Their understanding of dignity as a pool of personal capabilities has a practical application according to the authors. It makes possible to provide people with dignity or enabling them to feel dignified. They stated that the great majority of health professionals want to uphold human dignity, but without recognising dignity as a palpable concept, its' preservation is not an obvious practical priority. In a broader view, they added that providing people with dignity as a social priority would require political change in all western societies. Argue that dignity is something that must be sensed - to feel dignity or not is an experience.

Writing in 2004, one of the authors of this manuscript distinguished between dignity as a self-regarding and other-regarding value ${ }^{(34)}$. One of the most widely cited accounts of dignity in relation to nursing care is by the Norwegian philosopher, Lennart Nordenfelt, who distinguished amongst four 'varieties of dignity'(35-36) as follows:

- The dignity of Menschenwürde - is a German word meaning a kind of dignity we all have to the same degree just because we are all humans'.

- Dignity as merit - people have rights on the basis of holding certain roles or office or because they have earned merit through their actions. They have rights on the basis of this merit and are, therefore, treated as having a special dignity.

- The dignity of moral stature - This kind of dignity is based on the person's moral stature that comes from their actions and omissions and from the kind of people they are. There are degrees of it and it is dependent on subjects action so may come and go. People such as Nelson Mandela may be said to have dignity of moral stature.

- The dignity of personal identity - This kind of dignity is nursing practice and is related to one's identity as a person and is related to self-respect. It is related to concepts such as integrity, autonomy and inclusion. This kind of dignity can be taken away from people when, for example, they are humiliated, insulted or treated as objects.

Nordenfelt's four varieties of dignity has been critically analysed in relation to nursing practice in the journal Nursing Philosophy ${ }^{(37)}$.

This short overview of some of the key philosophical perspectives on dignity does not exhaust the possibilities. The concept of dignity has been examined, for example, through a historical lens by Rieke Van Der Graaf and Johannes Van Delden ${ }^{(38)}$. Their four forms of dignity are identified as: relational, unconditional, subjective and Kantian forms. Alasdair Cochrane describes four of the most plausible conceptions of dignity as: dignity as virtuous behaviour; dignity as inherent moral worth; Kantian dignity; and dignity as species integrity ${ }^{(39)}$. The Harvard philosopher Michael Rosen ${ }^{(40)}$ adopts a Kantian approach to the analysis of dignity and identifies four strands of dignity work: as a rank or status; as intrinsic value; as measured and self-possessed behaviour; and as relating to the idea that people 'should be treated with dignity'(40)

Another perspective is from the Spanish philosopher, Adela Cortina ${ }^{(41)}$, who states that each human being needs the acknowledgement of his/her dignity by others to develop well his/her capabilities. It is impossible for a person 
to recognize his/her own dignity if they are treated in a disrespectful manner. To be just, a society is obliged to ensure the promotion of the capabilities that make possible a dignified life. Only human beings may be conscious of their own dignity because they are able to feel humiliated, recognized, respected or disrespected. Other living beings may feel pleasure and pain but they are not able to be conscious of the dignity of its existence. An animal may be harmed but not humiliated; it may suffer but not be conscious that it is being depreciated due a violation of its rights. A human being needs self-esteem to live well and this depends on the treatment that others give to him/ her. Dignity is not a satisfied life; it is the acknowledgement that you are being treated according to the norm of the species which is liberty ${ }^{(41)}$.

These are only some of the many perspectives in the philosophical literature relating to dignity more generally and dignity in relating to care. What is clear is that there is no consensus, the concept remains contested and debate is likely to continue. We turn next to some of the critical accounts of dignity discourse.

\section{THE CONTESTED NATURE OF DIGNITY}

The American bioethicist, Ruth Macklin, described dignity as 'a useless concept'(1) and argued that autonomy was the more useful and necessary value. Her article in the British Medical Journal in 2003 generated a great deal of debate. Writing in the New Republic in 2008, Steven Pinker argued that the problem is that dignity is a squishy, subjective notion hardly up to the heavyweight moral demands assigned to $i t^{(2)}$.

Despite what appear to be these rather severe if not damning criticism of dignity in the context of bioethics, there continues to be a great deal of engagement with the concept in relation to everyday nursing practice, policy and research. We may say that the principle of respect for human dignity plays a crucial role in the emerging global norms relating to bioethics, in particular in the UNESCO Declaration on Bioethics and Human Rights. However, the key role attached to human dignity in global bioethics is necessary but not sufficient for providing an effective response to the complex challenges posed by biomedical and nursing clinical and research practice. Thus, to become functional, dignity needs other more concrete notions that are normally formulated using the terminology of rights, such as informed consent, physical integrity, confidentiality and non-discrimination ${ }^{(42)}$. Many empirical studies have been published in Nursing Ethics on this theme.

\section{DIGNITY AND NURSING ETHICS RESEARCH}

There has been a good deal of empirical research attention to the concept in dignity in relation to care. Nurse researchers, in particular, have conducted a wide range of qualitative research studies engaging patients and professionals to develop in-depth perspectives and discussions regarding the meaning and implications dignity in care ${ }^{(43-50,56-58)}$. There has also been some quantitative work in this area ${ }^{(51)}$. The themes suggested in the qualitative studies published in Nursing Ethics are wide-ranging and relate to specific patient groups. In relation to older nursing home residents in Sweden, for example, Franklin and co-researchers ${ }^{(43)}$ discuss themes of': the unrecognisable body (related to lack of control of physical functioning and movement); fragility and dependency (related to fears about the future, greater dependence on others and loss of autonomy); and 'inner strenght and sense of coherence' (related to strategies older people have to maintain dignity of identity). A study ${ }^{(44)}$ explored the perspectives of patients experiencing multiple sclerosis regarding dignity in their care. The resulting themes were: invisibly captured in fatigue; fighters law, one who does not ask will not receive; and dignity is humanity. There are an increasing number of qualitative studies on dignity from different parts of the world and many of these are published in Nursing Ethics. We recommend that readers conduct a search of this and other ethics, social science and professional journals to better appreciate the very rich, nuanced and subjective perspectives of patients and practitioners regarding dignity in care.

Some empirical studies have also provided guidance regarding factors that impact on dignity in care. A UK study of over 2000 nurses $^{(52)}$ and a UK literature review ${ }^{(53)}$ identified three broad areas that have the potential to enhance or diminish patient dignity in care. These are: staff attitudes and behaviour; the physical care environment; and organisational culture. Empirical work conducted outside of nursing research also has the potential to offer rich insights particularly into end of life care. The work of Chochinov, for example, regarding dignity therapy is particularly interesting ${ }^{(54-55)}$. In Brazil, the results of some empirical studies summarize the close relation of healthcare humanization and the protection of patients' dignity by a dialogical nurse-user relationship ${ }^{(56-58)}$.

\section{CONCLUSION}

In the light of the discussion in this article, we recommend more sustained philosophical engagement contextualising human dignity within a plurality of professional values. It is our view that, although dignity may be considered a foundational value particularly as it underpins human rights, it is not the only value that underpins healthcare practice. Nurses and other professionals need to engage with and apply a range of principles and virtues in their everyday practice, for example, justice, solidarity, compassion, courage and integrity. The authors suggest also that future empirical work should explore what matters to patients, families, professionals and citizens in dif- 
ferent cultural contexts rather than foregrounding qualitative research with such a contested concept. We also suggest that understanding and responding constructively to deficits in care requires multi-disciplinary perspectives.

\section{REFERENCES}

1. Macklin R. Dignity is a useless concept. BMJ. 2003;327 (7429):1419-20.

2. Pinker S. The stupidity of dignity. The New Republic [Internet]. 2008 May 28 [cited 2011 May 11]. Available from: http:// pinker.wjh.harvard.edu/articles/media/The\%20Stupidity\%20 of\%20Dignity.htm

3. London NHS Confederation. Commission on Dignity in Care Delivering Dignity: securing dignity in care for older people in hospitals and care [Internet]. 2012 [cited 2012 May 11]. Available from: http://www.nhsconfed.org/Publications/reports/ Pages/Delivering-Dignity.aspx

4. The Patients Association. Patients...not numbers, people... not statistics [Internet]. [cited 2011 May 11]. Available from: http://www.patients-association.com/Portals/0/Public/Files/ Research\%20Publications/Patients\%20not\%20numbers,\%20 people\%20not\%20statistics.pdf

5. The Patients Association. We've been listening: have you been learning? [Internet]. 2011 [cited 2012 May 11]. Available from: http://patients-association.com/default. aspx?tabid $=80 \& \mathrm{Id}=23$

6. The Care Quality Commission. National report on dignity and nutrition review published [Internet]. 2011 [cited 2012 May 11]. Available from: http://www.cqc.org.uk/public/news/national-report-dignity-and-nutrition-review-published

7. Health Service Ombudsman. Care and compassion? Report of the Health Service Ombudsman on ten investigations into NHS care of older people [Internet]. London; 2011 [cited 2012 May 11]. Available from: http://www.ombudsman.org.uk/_ data/assets/pdf_file/0016/7216/Care-and-Compassion-PHso-0114web.pdf

8. Mandelstam M. How we treat the sick: neglect and abuse in our health services. London: Jessica Kingsley; 2011.

9. Martin D. Health Minister backs Mail to end NHS neglect of the elderly. Mail Online [Internet]. [cited 2012 July 13]. Available from: http://www.dailymail.co.uk/news/article-1335591/Health-Minister-backs-Mail-campaign-end-NHS-neglect-elderly.html

10. Brigth M. A blow struck for dignity. The Observer Special Reports [Internet]. 2001 Apr 1 [cited 2011 May 11]. Available from: http://observer.guardian.co.uk/carehomes/story/0,,466446,00.html

11. BBC One Panorama. Undercover care: the abuse exposed [Internet]. 2011 May 31 [cited 212 July 12]. Available from: http://www.bbc.co.uk/programmes/b011pwt6
Nurse researchers and scholars should therefore, in addition to engagement with philosophical and empirical ethicists, work with lawyers, social and behavioural scientists to develop sustainable solutions.
12. BBC iPlayer. Panorama. Undercover: elderly care [Internet]. 2012 [cited 2012 July 15]. Available from: http://www.bbc. co.uk/iplayer/episode/b01gybn7/Panorama_Undercover_ Elderly_Care/

13. Brasil. Ministério da Saúde. Conselho Nacional de Secretários de Saúde. A saúde na opinião dos brasileiros. Brasília: CONASS; 2003.

14. Pasche DF, Passos E, Hennington EA. Five years of the national policy of humanization: the trajectory of a public policy. Ciênc Saúde Coletiva. 2011;16(11):4541-8.

15. Brasil. Ministério da Saúde; Secretaria de Atenção à Saúde. Núcleo Técnico da Política Nacional de Humanização. Acolhimento nas práticas de produção de saúde. 2a ed. Brasília; 2006. (Série B. Textos Básicos de Saúde).

16. Pessini L, Barchifontaine CP. An X-Ray of Bioethics in Brazil: Pioneering voices, institutional and educational programs and perspectives. In: Pessini L, Barchifontaine CP, Lolas F. editors. Ibero-American Bioethics: history and perspectives. New York: Springer; 2010. p. 89-106.

17. Schramm FR. Bioética da proteção: ferramenta válida para enfrentar problemas morais na era da globalização. Bioética. 2008;16(1):11-23.

18. Pauly B, Varcoe C, Storch J, Newton L. Registered nurses perceptions of moral distress and ethical climate. Nurs Ethics. 2009;16(5):561-73.

19. Schluter J, Winch S, Holzhauser K, Henderson A. Nurses moral sensitivity and hospital ethical climate: a literature review. Nurs Ethics. 2008;15(3):304-21.

20. Olson LL. Hospital nurses perception of the ethical climate of their work setting. Image J Nurs Sch. 1998;30(4):345-9.

21. Solum EM, Slettebo A, Hauge S. Prevention of unethical actions in nursing homes. Nurs Ethics. 2008;15(4):536-48.

22. Pessini L. Qual antropologia para fundamentar a bioética em tempo de incertezas? In: Pessini L, Siqueira JE, Hossne WS, organizadores. Bioética em tempos de incertezas. São Paulo: Loyola/Centro Universitário São Camilo; 2010. p. 23-40.

23. Gan S. Human dignity as a right. Front Philos China. 2009;4(3):370-84.

24. United Nations. Department of Public Information. Universal Declaration of Human Rights, 1948 [Internet]. [cited 2011 Dec 14]. Available from: http://www.un.org/events/ humanrights/2007/hrphotos/declaration\%20_eng.pdf 
25. Ward T, Syversen K. Human dignity and vulnerable agency: an ethical framework for forensic practice. Aggress Violent Behav. 2009;14(2):94-105.

26. United Kingdom. Human Rights Act, 1998 [Internet]. [cited 2011 Feb 17]. Available from: http://www.legislation.gov. uk/ukpga/1998/42/contents

27. Rothlaar M. Human dignity and human rights in bioethics: the Kantian approach. Med Health Care Philos. 2010;13(2):251-7.

28. National Health Service. The handbook to the NHS Constitution, 2012 [Internet]. [cited 2011 Feb 11]. Available from: http://www.dh.gov.uk/prod_consum_dh/groups/dh_digitalassets/@dh/@en/documents/digitalasset/dh_132959.pdf

29. International Council of Nurses (ICN). Code of Ethics for Nurses, 2006 [Internet]. [cited 2011 Feb 11]. Available from: https://www.icn.ch/about-icn/code-of-ethics-for-nurses/

30. Nursing \& Midwifery Council. The code: standards of conduct, performance and ethics for nurses and midwives. London: NMC; 2008.

31. Conselho Federal de Enfermagem. Resolução COFEN n. 311, de 8 de fevereiro de 2007. Aprova o Código de Ética dos Profissionais de Enfermagem. Rio de Janeiro; 2007.

32. Jacobson N. Dignity and health: a review. Soc Sci Med. 2007;64(2):292-302.

33. Seedhouse D, Shotten L. Practical dignity in caring. Nurs Ethics. 1998;5(3):246-55.

34. Gallagher A. Dignity and respect for dignity: two key health professional values: implications for nursing practice. Nurs Ethics. 2004;11(6):587-99.

35. Nordenfelt L. The varieties of dignity. Health Care Anal. 2004;12(2):69-81.

36. Nordenfelt L, editor. Dignity in care for older people. New York: John Wiley \& Sons; 2009.

37. Wainwright $P$, Gallagher A. On different types of dignity in nursing care: a critique of Nordenfelt Nurs Philos. 2008;9(1):46-54.

38. Van Der Graaf R, Van Delden J. Clarifying appeals to dignity in medical ethics from and historical perspective. Bioethics. 2009;23(3):151-60.

39. Cochrane A. Undignified bioethics. Bioethics. 2010;24(5): 234-41.

40. Rosen M. Dignity: its history and meaning. Cambridge: Cambridge Harvard University Press; 2012.

41. Cortina A. Las fronteras de la persona: el valor de los animales, la dignidad de los humanos. Madrid: Taurus; 2009.
42. Andorno R. Human dignity and human rights as a common ground for a global bioethics. J Med Philos. 2009;34(3):223-40.

43. Franklin LL, Ternestedt BM, Nordenfelt L. Views on dignity of elderly nursing home residents. Nurs Ethics. 2006;13(2):130-46.

44. Lohne V, Aasgaard T, Caspari S, Slettebø A, Nåden D. The lonely battle for dignity: individuals struggling with multiple sclerosis Nurs Ethics. 2010;17(3):301-11.

45. Bredenhof Heijkenskjöld K, Ekstedt M, Lindwall L. The patient's dignity from the nurse's perspective. Nurs Ethics. 2010;17(3):313-24.

46. Jakobsen R, Sørlie V. Dignity of older people in a nursing home: narratives of care providers. Nurs Ethics. 2010;17(3):289-300.

47. Lundqvist A, Nilstun T. Human dignity in paediatrics: the effects of health care. Nurs Ethics. 2007;14(2):215-28.

48. Wadensten B, Ahlström G. The struggle for dignity by people with severe functional disabilities. Nurs Ethics. 2009;16(4):453-65.

49. Reed $P$, Smith $P$, Fletcher $M$, Bradding A. Promoting the dignity of the child in hospital. Nurs Ethics. 2003;10(1):67-76.

50. Stabell A, Nåden D. Patients' dignity in a rehabilitation ward: ethical challenges for nursing staff. Nurs Ethics. 2006;13(3):236-48.

51. Nayeri HD, Karimi R, Sadeghee T. Iranian nurses and hospital teenagers' views of dignity. Nurs Ethics. 18(4):474-84.

52. Baillie L, Gallagher A, Wainwright P; Royal College of Nursing. Defending dignity in care: challenges and opportunities for Nurses. London: Royal College of Nursing; 2008.

53. Gallagher A, Li S, Wainwright P, Rees Jones I, Lee D. Dignity in the care of older people: a review of the theoretical and empirical literature. BMC Nurs. 2008;7:11.

54. Chochinov HM. Dignity in the terminally ill: a cross-sectional, cohort study. Lancet. 2002;360(9350):2026-30.

55. Chockinov HM. Dignity therapy: final words for final days. Oxford: Oxford University Press; 2012.

56. Santana JCB, Campos ACV, Dutra BS, Borges CM, Souza AB, Santos VH. O cuidado humanizado sob a percepção dos enfermeiros. Enferm Rev. 2012;15(1):47-57.

57. Fontes CAS, Alvim NAT. Human relations in nursing care towards cancer patients submitted to antineoplastic chemotherapy. Acta Paul Enferm. 2008;21(1):77-83.

58. Kaneji S, Costa TL, Formozo GA, Silva SA. Educação em saúde como estratégia para garantir a dignidade da pessoa humana. Rev Bras Enferm. 2004;57(5):617-9. 